\title{
"Why Do We Celebrate ...?" Filling Traditions with Meaning in an Ethnically Diverse Swedish Preschool
}

\author{
Tünde Puskás ${ }^{1}$ (D) Anita Andersson ${ }^{1}$
}

Published online: 16 February 2017

(C) The Author(s) 2017. This article is published with open access at Springerlink.com

\begin{abstract}
The Swedish preschool is an important socializing agent because the great majority of children aged, from 1 to 5 years, are enrolled in an early childhood education program. This paper explores how preschool teachers and children, in an ethnically diverse preschool, negotiate the meaning of cultural traditions celebrated in Swedish preschools. Particular focus is given to narrative representations of cultural traditions as they are co-constructed and negotiated in preschool practice between teachers and children. Cultural traditions are seen as shared events in the children's preschool life, as well as symbolic resources which enable children and preschool teachers to conceive themselves as part of a larger whole. The data analyzed are three videotaped circle time events focused on why a particular tradition is celebrated. Methodologically the analysis builds on a narrative approach inspired by Bakhtin's notion of addressivity and on Alexander's ideas about dialogic teaching. The results of the analysis show that the teachers attempt to achieve a balance between transferring traditional cultural and religious values and realizing a child-centered pedagogy, emphasizing the child's initiative. The analyses also show that narratives with a religious tonality generate some uncertainty on how to communicate with the children about the traditions that are being discussed. These research findings are important because, in everyday practice, preschool teachers enact whether religion is regarded as an essential part of cultural socialization, while acting both as keepers of traditions and agents of change.
\end{abstract}

Keywords Preschool - Circle time - Dialogic teaching - Cultural traditions · Cultural narrative

Tünde Puskás

tunde.puskas@liu.se

1 Department of Social and Welfare Studies, Linköping University, Holmentorget 10, 60174 Norrköping, Sweden 
Résumé Le préscolaire suédois est un agent de socialisation important parce que la grande majorité des enfants âgés de 1 à 5 ans sont inscrits à un programme d'éducation de la petite enfance. Cet article explore la façon dont les enseignants et les enfants d'âge préscolaire, dans un centre préscolaire ethniquement diversifié, négocient le sens des traditions culturelles célébrées dans les centres préscolaires suédois. Une attention particulière est accordée aux représentations narratives des traditions culturelles comme elles sont co-construites et négociées entre les enseignants et les enfants dans la pratique préscolaire. Les traditions culturelles sont vues comme des événements partagés dans la vie préscolaire des enfants, ainsi que comme des ressources symboliques qui permettent aux enfants et aux enseignants du préscolaire de se concevoir eux-mêmes comme partie d'un tout plus vaste. Les données de recherche rapportées comprennent trois événements de la causerie, enregistrés sur vidéo, axés sur la raison pour laquelle une tradition particulière est célébrée. Sur le plan méthodologique, les analyses s'appuient sur une approche narrative inspirée de la notion d'addressivité de Bakhtine et sur les idées d'Alexander sur l'enseignement dialogique. Les résultats de l'analyse montrent que les enseignants tentent d'atteindre un équilibre entre le transfert de valeurs culturelles et religieuses traditionnelles et la réalisation d'une pédagogie centrée sur l'enfant, mettant l'accent sur l'initiative de l'enfant. Les analyses montrent également que les récits avec une tonalité religieuse génèrent de l'incertitude sur la façon de communiquer avec les enfants sur les traditions qui sont en cours de discussion. Ces résultats de recherche sont importants car, dans la pratique quotidienne, les enseignants du préscolaire représentent que la religion est considérée comme une partie essentielle de la socialisation culturelle, tout en agissant à la fois en tant que gardiens des traditions et agents de changement.

Resumen El preescolar sueco es un importante agente socializador, ya que la gran mayoría de los niños entre 1 y 5 años están inscritos en un programa de educación para la primera infancia. Este documento explora cómo los profesores y niños, en un preescolar de diversidad étnica, negocian el significado de las tradiciones culturales celebradas en preescolares suecos. El foco particular está dado a las representaciones narrativas de las tradiciones culturales mientras son co-construidas y negociadas en prácticas preescolares entre profesores y niños. Las tradiciones culturales son vistas como eventos de convivencia en la vida preescolar de los niños, además como recursos simbólicos que permiten a los niños y a sus profesores concebirse a sí mismos como parte de un mundo más amplio. Los datos de investigación reportados comprenden tres eventos de tiempo de círculo grabados en video enfocados en por qué se celebra una tradición particular. Metodológicamente, el análisis construye un acercameinto narrativo inspirado en la noción de dirección de Bathkin y en las ideas de Alexander acerca de la enseñanza dialógica.

\section{Introduction}

In Sweden, over $80 \%$ of all children between 1 and 5 years are enrolled in preschool education (Swedish National Agency for Education 2013, p. 10). Thereby the Swedish preschool can be seen as an important socializing agent that prepares 
children to conform to the fundamental values on which the Swedish society is based (Alvestad and Samuelsson 1999). According to the Swedish Preschool Curriculum one of the tasks of the preschool is to pass on "a cultural heritage ... from one generation to the next" (Swedish National Agency for Education 1998/ 2010 , p. 5). The formulation indicates that cultural heritage plays an important role in defining the tasks of preschool teachers as far as the transmission of cultural norms is concerned. At the same time, while cultural heritage is conceptualized in terms of "values, traditions and history, language and knowledge" (Swedish National Agency for Education 1998/2010, p. 5), it is not explicitly stated whether or not religion is seen as part of the cultural heritage. Moreover, the Swedish Education Act stipulates that education in all preschools should be nonconfessional.

With these points of departure in mind, the aim of the overall research project of which this study is a part, is to explore how preschool teachers understand and enact the relationship between cultural heritage, tradition and religion and whether religion is regarded as an essential part of cultural socialization in everyday preschool practice. This study focuses specifically on how preschool teachers and children in an ethnically diverse Swedish preschool address three traditions celebrated in the preschool, Easter, Christmas and Valentine's Day during circle time.

The Swedish Preschool Curriculum envisages teachers as active, guiding and challenging. In the same spirit, the curriculum envisages children as competent while it is stated that a child's competence in different areas will be expanded in interaction with peers and teachers (Pramling Samuelsson and Asplund Carlsson 2003). Thus, children and preschool teachers are seen as learning partners instead of being treated as transmitters and recipients of cultural values (cf. Ødegaard 2007). At the same time, structured as a teacher-led activity, circle time involves an educational dilemma about how teachers balance the ideals of the curriculum to view children as learning partners and the aim of the structured activity.

\section{Theoretical and Conceptual Framework}

The specific aim of the circle time discussions analyzed in this paper was to involve the children in a discussion on "why do we celebrate" a particular tradition. The concept of tradition is seen here as "a set of practices, normally governed by overtly or tacitly accepted rules and of a ritual or symbolic nature, which seek to inculcate certain values and norms of behavior by repetition, which automatically implies continuity with the past" (Hobsbawn 1983, p. 1). One way of transmitting cultural and moral values in preschool practice is through cultural narratives, conceptualized elsewhere as retold stories, which "serve to initiate children into aspects of a social heritage, transmitting many of a culture's central values and assumptions" (Stephens and McCallum 1998, p. 3). Nevertheless, we do not consider retellings of traditional stories such as Biblical stories, myths, hero stories, folktales, fairy tales and modern classics simply as replications. Instead, building on the research of Stephens and McCallum (1998), we suggest that retellings of cultural narratives are infused with the cultural and ideological perspectives of their historical period as 
well as of a metaethic that "expresses a culture specific idea of a transcendence and not universal" (p. 7).

Within the educational context, narratives are seen as basic devices for socialization in a culture, as well as instruments of meaning making (Bruner 1984). As Bruner (1996) formulates it "It is only in the narrative mode that one can construct an identity and find a place in one's culture" (p. 41). However, "if narrative is to be made an instrument of mind on behalf of meaning making, it requires work on our part-reading it, making it, analyzing it, understanding its craft, sensing its uses, discussing it" (Bruner 1996, p. 41). As the traditions chosen for the circle time sessions can be associated with both secular and religious stories and rites it is appropriate to discuss how circle time can be used to bring children together to talk about particular traditions as well as the dilemmas associated with the framing of circle times.

Circle time is in itself a tradition that plays, among other things, an important role in communicating cultural narratives (Reich 1994). Circle time has been characterized both as a social event and as a disciplining ritual of order (Reich 1994; Ehn 1983). It is also a teaching strategy that enables early years practitioners to "deliver the curriculum for personal, social and emotional development, while at the same time, helping children to understand universal moral values and practice problem solving skills" (Mosley 2005, p. vii). Nevertheless, within the Swedish preschool where children's participation in their education is part of a democratic ideal, teachers have to balance between treating children as cultural adapters and as anticipated contributors (Ødegaard 2007). This is why the co-constructions of narratives can be treated as an inherently responsive activity (Bakhtin 1986), as well as a means of dialogical teaching (Alexander 2006).

According to Bakhtin's (1986) theory of dialogical meaning making all utterances has an intended audience, addressivity. Utterances are defined as units of speech communication and as concrete realizations of language. Individuals give voice to meaning in their utterances but an "utterance is related not only to preceding, but also to subsequent links in the chain of speech communion" (Bakhtin 1986, p. 94). As Bakhtin (1986) explains: "When a speaker is creating an utterance, of course, these links do not exist. But from the very beginning the utterance is constructed while taking into account possible responsive reactions, for whose sake, in essence, it is actually created. As we know the role of the others for whom the utterance is constructed is extremely great" (p. 94). Consequently, addressivity implies that those who speak are oriented toward a responsive understanding. An individual (author) producing an utterance reflects or considers the addressee, the person or persons to whom the utterance is addressed. For example, consider the following utterance from our material: When the teacher asked: "Do you know why we celebrate Valentine's day?" and the children answered "No," the teacher modified her question and asked "What do you think?" Thus, the teacher's second question considers the children's lack of experiences (expressed in their answer) and creates a link in the chain of speech communion.

Bakhtin has also been influential on Alexander's ideas about dialogic teaching. Alexander's (2006) point of departure was to question the epistemological dominance of the teacher in whole class interactions in schools. We consider his 
ideas transferable into early childhood educational settings, especially in the case of circle times, which is a teacher-led pedagogical situation. Alexander (2006) identifies essential features of the dialogic classroom as:

- Collective teachers and children address learning tasks together, whether as a group or a class, rather than in isolation;

- Reciprocal teachers and children listen to each other, share ideas and consider alternative viewpoints;

- Supportive children articulate their ideas freely, without fear of embarrassment over "wrong" answers, and they help each other to reach common understandings;

- Cumulative teachers and children build on their own and each others' ideas and chain them into coherent lines of thinking and enquiry;

- Purposeful teachers plan and facilitate dialogic teaching with particular educational goals in view.

Alexander's model of dialogic teaching is in line with the idea that children are agents of their own learning, which is one of the basic tenets of the Swedish preschool curriculum, according to which:

A sense of exploration, curiosity and desire to learn should form the foundations for the preschool activities. These should be based on the child's experiences, interests, needs and views. The flow of the child's thoughts and ideas should be used to create variety in learning (The Swedish National Agency for Education 1998/2010, p. 9).

Thus, one of the tasks of preschool teachers is to enable collaborative meaning making through building on the children's own ideas and experiences. At the same time, for dialogic teaching to be purposeful it has to involve one or a few educational goals and a shared pedagogical focus. In this research context we assume that during circle times, which focus on the question: "Why do we celebrate...?" It is the cultural narratives that provide a sufficient answer to this question that ought to constitute an educational goal.

\section{Methodology}

The data for this paper are drawn from fieldwork carried out in 2015-2016 in the form of video ethnography. On one occasion when we (the researchers) went to observe how the preschool celebrated Halloween we noticed a mindmap posted on the wall that focused on the question, "Why do we celebrate Halloween?" The mindmap contained answers ranging from "Because Halloween is God's birthday" to "Because we like to dress in scary/creepy stuff." The range of answers aroused our interest in how the mindmap was created. The teachers explained that the mindmap was a result of a circle time focusing on why Halloween was celebrated and that the same question would be posed about three other traditions celebrated during the school year: Christmas, Valentine's Day and Easter. The material 
analyzed for this paper consists of three video-filmed circle time occasions focusing on the same question: Why do we celebrate... (Christmas, Valentine day, Easter)? In addition, we will present the mindmaps that were produced during these circle times.

The preschool group for this fieldwork involved 19 children (aged 3-5 years old) and four teachers. The child group is diverse in terms of culture, religion and language. Five children speak Swedish as their mother tongue; one child who is Bosnian-Swedish is bilingual; nine children are Arabic-Swedish bilingual speakers; and four children are emergent Arabic-Swedish bilingual speakers. Some of the children come from secular family homes, others from Christian or Muslim homes. The most visible religion for the group is Orthodox Christian because the teachers "know" that their colleague Maria and some of the children practice Orthodox Christianity at home.

The four teachers represent diverse ethnic and professional backgrounds too. Anna and Susie have a Swedish background. Anna is a preschool teacher and Susie is a childminder. ${ }^{1}$ Alfredo has a Chilean background and works as a childminder. Maria, who is originally from Syria, is employed as a childminder with a specific language competence because newly arrived children are in need of language support. Maria helps these children to understand what is going on through interpreting and also by finding parallels between their first language and Swedish in order to support children's bilingual development.

Information about the study was given to the teachers, children and parents and written approval was obtained from the parents and the teachers. The children were asked to provide an oral consent. In the study both the teachers and the children are given fictitious names.

\section{Findings}

The empirical data were analyzed through a narrative analysis with a focus on how stories were constructed in collaboration between the children and the teachers. The transcriptions of the three circle time discussions were divided by ethnographic chunks that indicate a shift in the activity and provide a manageable set of units for analysis. An ethnographic chunk marks an event within an interaction sequence that "cohere in some manner that is meaningful to participants" (Jordan and Henderson 1995, p. 57). When identifying ethnographic chunks we were looking for turns in talk that were judged to be significant for the outcome of the discussion. The observed circle times had specific organizational beginnings and endings. The children and the teachers sat in a circle, one teacher had the main responsibility for structuring the activity in terms of asking questions and allocating speaking turns while another teacher had responsibility to document the answers on a mindmap.

The transcriptions were divided into 97 ethnographic chunks, which define narrative events in an interaction sequence. Of these events, 73 of these narrative

\footnotetext{
${ }^{1}$ Childminders are adults working in early childhood education services who are (or are expected to be) trained at upper secondary level and together with preschool teachers work with children aged 0-6.
} 
events focused on one of the following questions: "Why do we celebrate?"; "What do you think (why do we celebrate)?"; and "How do/did you celebrate at home/in the preschool/in Sweden?" All three circle times started with the question "Why do we celebrate?" As the example below illustrates when the children's answers are not an answer to a why-question the teacher modifies her questions.

\section{Example 1: Analysis of a Circle Time About “Why Do We Celebrate Easter?"}

In this example there are seven participants, three teachers Susie, Anna and Maria and four children Daniel (6.1 years), Samuel (4.6 years), Salma (6.2 years) Albert (4.8 years) and Ilona (5.11 years). For the sake of clarity in the analysis the example is divided into two sections.

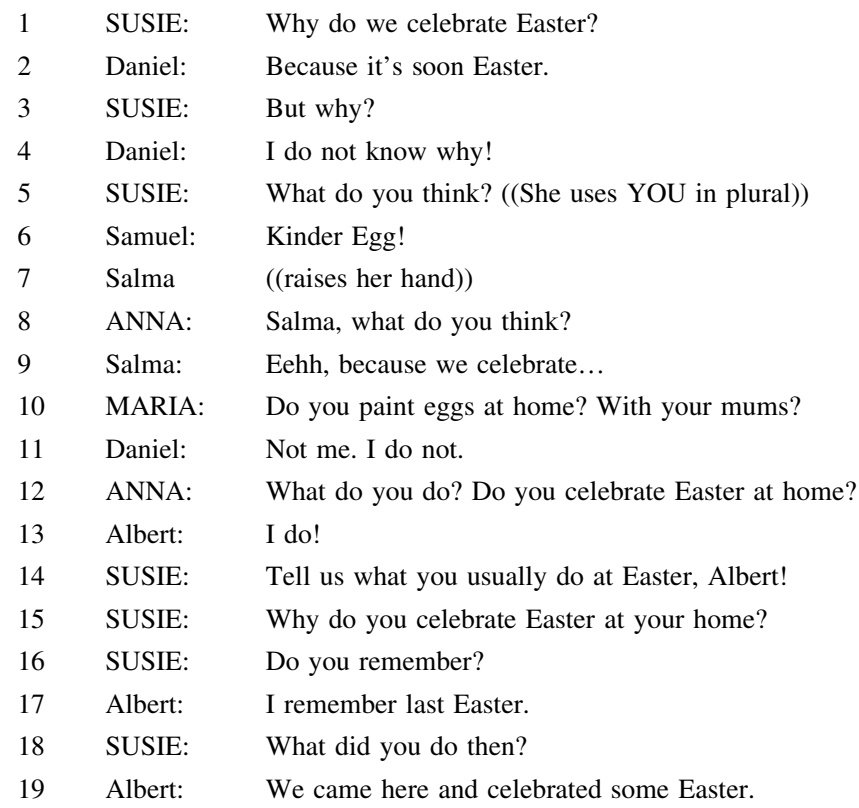

The why-question (line 1) builds on the assumption that the children do possess knowledge about the tradition discussed. The question, relating to a We (line 1), also assumes that there is a cultural narrative the children can relate to. When Daniel, a child with an Orthodox Christian background answers that he did not know why Easter is celebrated (line 4), Susie, the teacher, modifies the question and asks "What do you think?" (line 5). This question opens up for both interpretations of earlier experiences with a tradition and guesses. The children's ideas and beliefs disseminated in their answers reveal that they do not possess a collective story tied to the tradition discussed. The teachers Susie, Anna and Maria try to maintain a chain of utterances in different ways. Anna solicits answers to the question "What do you think?" from individual children, while Susie slips into the question "How 
do you celebrate?" by asking Albert about what he usually does at Easter (lines 14, $15,16,18)$. Several other children bring in their experiences with "things" related to the tradition such as Kinder-eggs, chocolate eggs, eggs, Easter bunny and sweets (Fig. 1). At the same time, building on the children's utterances, the teachers try to bind the pieces into a chain of events.

From a Bakhtinian perspective we can understand the teachers' questions as dialogic responses to the children's answers. All through the discussion the teachers modify their questions, as a reaction to the children's utterances, thereby keeping the dialogue flowing. The teachers do accept any answer and encourage the children to bring in their own experiences. However, the children do not seem to have enough knowledge about the cultural narratives tied to Easter, and their experiences of the tradition are fragmented. Nevertheless, most of the answers are documented on the mindmap without any remarks and everybody's answer is taken seriously no matter its content and whether it is an answer to the question or not. All answers are given the same epistemological status (Fig. 1).

This is why in our analysis we paid special attention to those narratives which were offered by the teachers as attempts to create coherence in the discussion, we call these narratives, offered narratives. Offered narratives are characterized by addressivity, that is, they are audience oriented utterances. They are offered by the teachers as attempts to create a flow between preceding and subsequent links in the chain of speech communion. Most of the narratives offered by they teachers are based on the teachers' experiences and expectations of what the children might have experiences of.

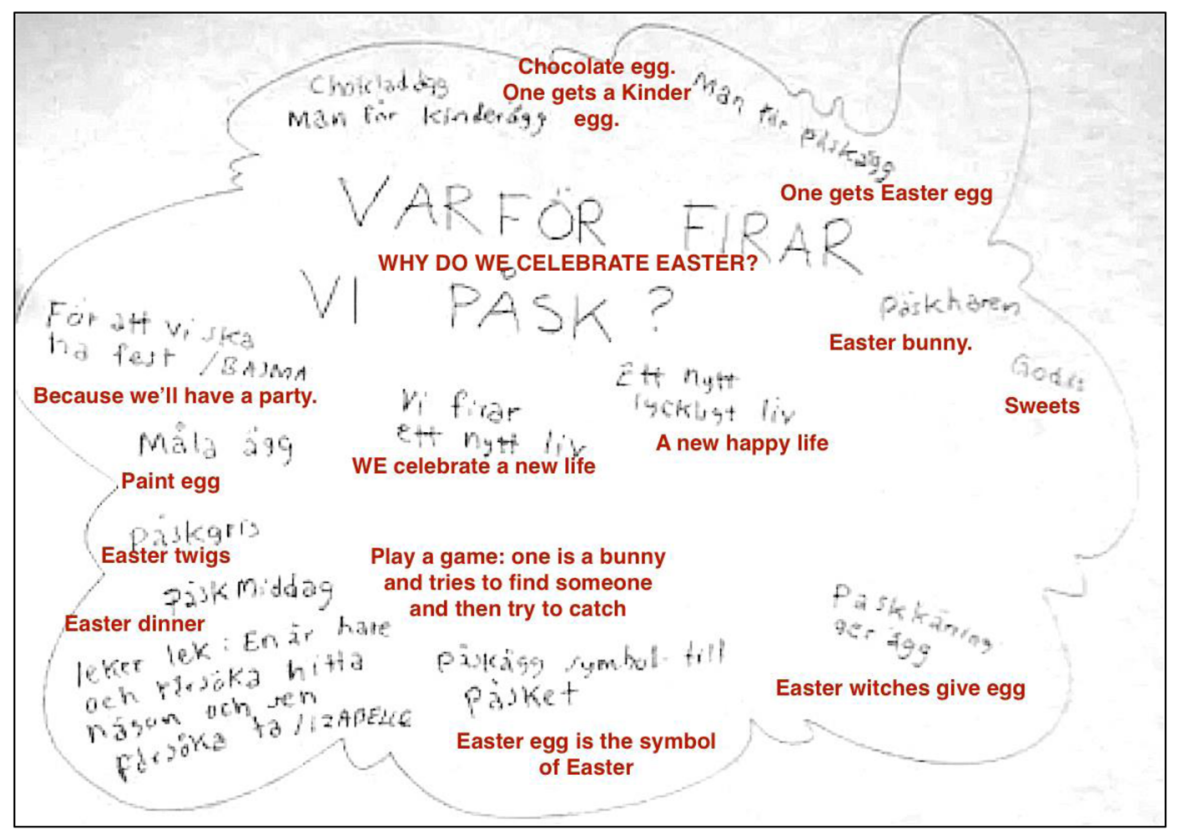

Fig. 1 Mindmap constructed from children's responses to the teacher's question: "Why do we celebrate Easter?" 
Six of the seven narratives offered by the teachers during circle time about Easter do not answer the question "why." Instead they involve suggestions about how the tradition is celebrated and what artifacts can be associated with it. These narratives are short, mostly one-liners, sometimes offered in a question form: "Do you paint eggs at home?" "Did you get Easter eggs?" "Did you eat Easter food?" Two other offered narratives were statements. The first about Easter being celebrated once a year, offered by Susie; and the second about the Easter egg being the symbol of a new life, offered by Maria. The sixth offered narrative related to how Easter would be celebrated in the preschool is told by Susie: "You can come to the preschool and dress up to Easter witches, Easter bunnies and we will fly to Blåkulla" (an imaginary place where the witches meet). Susie does not develop the Blåkulla narrative, probably because Albert picks up on the first part of Susie's statement and says that he will dress as Easter bunnie (at the preschool party). The seventh offered narrative and the only narrative that answers the question WHY we celebrate Easter appears first after 258 turns when Susie refers back to Maria's narrative on celebrating a new life:

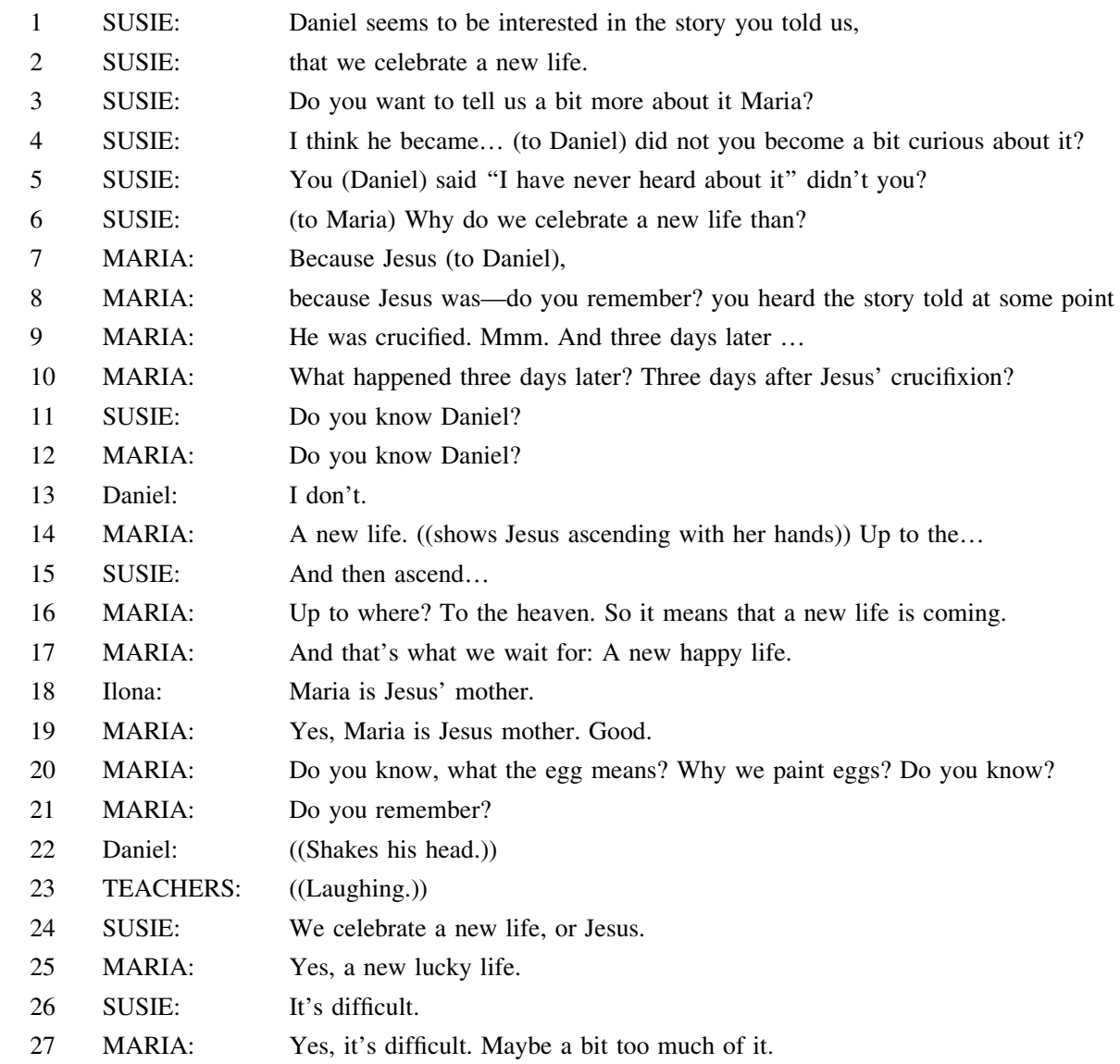


The example starts with Susie's remark about Daniel being interested in the story Maria introduced earlier, about celebrating a new life at Easter. Daniel is one of the 5 years old children who the teachers know has an Orthodox Christian background. Susie, a childminder with a Swedish background, wants Maria to tell the narrative she has on her mind while using Daniel's alleged interest in the story about why a new life is celebrated at Easter (lines 1, 2, 4, 5). At the same time Susie's urging to Maria to tell "the story" is getting stronger (lines 3, 6). Maria takes over Susie's strategy of using Daniel's alleged interest in the story as a narrative vehicle (lines 7, $8,12,21)$. The narrative about Easter being the celebration of Jesus' resurrection is at the end offered by Susie through Maria and Daniel. All three Susie, Maria and Daniel, seem uncomfortable with the situation. Susie seems to distance herself from this narrative, even if her remark in lines 15 and 24 reveals that she is familiar with it. Maria and Daniel are at the same time pointed out as "the owners" of the narrative. Ilona, who also has a Christian background, shows in line 18 that she is familiar with the main character in the Christian narrative. Maria affirms her knowledge (line 19) but does not treat Ilona's utterance relevant in the given context, probably because it is not in line with what she wants the other children to learn about. Instead of taking the opportunity to build on Ilona's utterance and chain it into the cultural narrative about why Easter is celebrated she returns to her own story about painting eggs (line 20).

In this example the teachers appear uncertain about the Easter narrative's religious aspect. We do not know whether this uncertainty depends on the teachers' limited knowledge about the religious aspects of Easter or on their lack of didactic knowledge about how to explain the narrative about Jesus's death, crucifixion and resurrection in a meaningful way. As a consequence, the circle time does not fulfill its potential to become cumulative and purposeful. The teachers open up for collaborative meaning making through building on the children's own ideas and experiences but the children and the teachers do not seem to reach a shared pedagogical focus when it comes to the narrative about Jesus. Instead, the two teachers involved in the discussion acknowledge that the task is difficult (lines 26, 27). The mindmap (Fig. 1) illustrates that the teachers do not chain the children's ideas into a coherent whole. Thus, the mindmap is an image of what has been said about Easter during circle time but it does not reflect the common sense cultural narrative about why Easter is celebrated.

A similar process and mindmap pattern can be observed in the discussions and the mindmaps about Christmas and Valentine's day. Nevertheless, when comparing the three discussions we have discovered that the three examples differ in one critical respect: namely, what cultural narratives are offered by the teachers and how these narratives are incorporated into the discussion as a whole.

\section{Example 2: Analysis of a Circle Time About "Why Do We Celebrate Christmas?"}

Similarly to the discussion on Easter, the discussion about why Christmas is celebrated shifts between why-, what- and how-questions. The six offered narratives which answer the why-question are longer than the ones about Easter in the previous 
example, and relate to the learning content identified by the teachers as a desired outcome of collaborative meaning making. For example, during circle time about Christmas, Maria introduced the religious narrative about Christmas saying "I think we celebrate Christmas because it's Jesus birthday." Her utterance was a direct response to her colleagues' Anna's question "Should we ask Maria, why she celebrates Christmas?" Anna's question is directed to Maria probably because she is expected to be knowledgeable about the religious background of the Christmas tradition. Maria's answer is followed by an utterance from Albert (4.8 years), who says, "It was my birthday' whereby religious narrative offered by Maria is interrupted. She makes two more attempts to get back to the narrative about Christmas being the celebration of Jesus' birthday, but she is interrupted both times and thereby the narrative offered by her runs out of steam. On the mindmap about Christmas (Fig. 2) Maria's offered narrative is one of many ideas about why and how Christmas is celebrated. However, in spite of this, when Anna summarizes the discussion at the end she gets back to the religious narrative offered by Maria: "Now, my friends, we've got very lovely replies from you. What a joy it is to listen to your thoughts about how you celebrate Christmas, and why you celebrate it. And it is, as Maria says,- -we celebrate Christmas, because it's Jesus's birthday."

The last utterance is more a reflection of what the teachers consider as a reliable and relevant answer to the question the circle time focused than a summary of what has been said. It is also worth noticing that Anna refers to Maria, a teacher with a foreign and a religious (Orthodox Christian) background as the "owner" of the narrative about Jesus' birthday, even if she marks that Christmas is celebrated by a collective pronoun "We." Thus, the narrative about "why we celebrate Christmas" is offered and avoided at the same time. Avoided in terms of attributing the narrative about Jesus birthday to Maria, while confirming that Christmas is indeed a celebration of the birthday of Jesus. This positioning reveals some ambiguity as far as offering religious narratives about a tradition that was originally tied to Christianity.

Our suspicion that narratives with a religious background were considered sensitive was confirmed when we compared them to the narratives disseminated during a third circle time event about why we celebrate Valentine's Day.

\section{Example 3: Analysis of a Circle Time About "Why Do We Celebrate Valentine's Day?"}

Valentine's Day, called “All Heart's Day" in Swedish, is not a traditional holiday in Sweden. On a broader scale it has been celebrated since the 1990 s, mostly as a result of commercial marketing (Lilja 1998). It is not perceived as a holiday with religious/Christian roots and it is not listed among Swedish traditions (Swahn 2012). In a study on how Valentine's day and Halloween have become new traditions Lilja (1998) found that beside the commercial interests there is a humanitarian ideology tied to "All Heart's Day" and that's why it is readily used by humanitarian and other nonprofit organizations to appeal to people's emotions and feelings of solidarity. Lilja has also found that starting from those who were children in the 


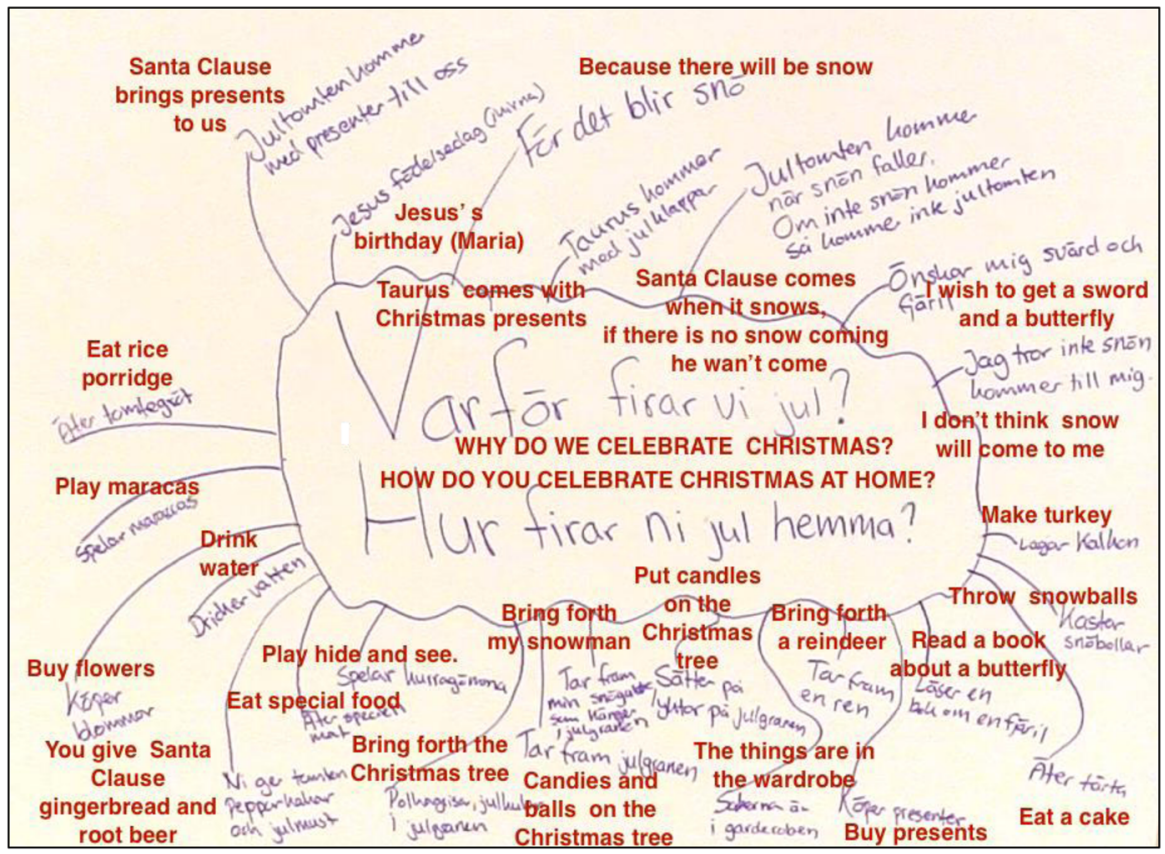

Fig. 2 Mindmap constructed from children's responses to the teacher's question: "Why do we celebrate Christmas?"

1990s people have memories of celebrating Valentine's day in preschool. According to Lilja's (1998) study, preschools and school have played an important role in spreading the tradition, for example, in the form of offering heart-formed sweets and making heart-formed cards. In the preschool our fieldwork was conducted in the preparations started with a circle time on "Why do we celebrate Valentine's day?"

The circle time, as in the case of the Christmas, starts with the question "Why?" but when the children's utterances "No," "Because it's soon Easter," "Because the winter is soon over" does not give a satisfactory answer, the teacher, Anna, turns to the question "Have you ever celebrated Valentine's day at home?" Anna asks both the children and the teachers Maria and Alfredo, but only Maria gives a positive answer saying the she usually bakes a heart-formed cake that day. Until this point the discussion is similar to the one on why Christmas and Easter are celebrated. However, after fourteen turns, Anna changes her focus on the children's own stories and introduces an offered narrative, through a book the children are familiar with.

In this example there are two teachers, Anna and Alfredo, and several children participating. Apart from Daniel (6.1 years) there is a collective voice of a group of children answering the teachers' questions. 


\begin{tabular}{|c|c|c|}
\hline 1 & ANNA & Do you remember the book we have read about the Frog and the Duck? \\
\hline 2 & Children & Aa, yes, jaa. \\
\hline 3 & ANNA & What is it about? \\
\hline 4 & Daniel & Love! \\
\hline 5 & ANNA & What do you think Valentine's day is about? \\
\hline 6 & Children & Love! \\
\hline 7 & $\ldots$ & \\
\hline 8 & ANNA & How can one show that she/he is in love? \\
\hline 9 & ANNA & Do you remember that we talked about it when we had book-reading? \\
\hline 10 & ANNA & You talked with Alfredo about... \\
\hline 11 & ALFREDO & We talked about it last week, do you remember? \\
\hline 12 & ANNA & What does it feel to be in love with someone? \\
\hline 13 & Daniel & Warm and cold! \\
\hline 14 & ANNA & But: Can love be in several ways than between a girl and a boy? \\
\hline 15 & ANNA & Girl and girl, boy and boy? \\
\hline 16 & Daniel & Yes. One can be in love girl and girl and boy and boy. \\
\hline 17 & $\cdots$ & \\
\hline 18 & ALFREDO & Yes, do you remember the book we have read? The frog and the duck. \\
\hline 19 & Children & Yees! \\
\hline 20 & ALFREDO & Whom falls the frog in love with? \\
\hline 21 & Children & In the duck. \\
\hline 22 & ANNA & It (the book) shows that one can fall in love with anyone. \\
\hline 23 & ANNA & It does not play any role what one looks like or who one is. \\
\hline
\end{tabular}

Anna's questions in lines 1, 3, 5 suggest to the children what answers are desired. Anna's questions also lead toward a particular educational goal, which is to discuss broad-mindedness as far as love is concerned (lines 14, 15, 16, 22, 23). In this situation Anna is the main facilitator but solicits help from her colleague Alfredo to build up an offered narrative (lines $9,10,11,18$ ). The discussion can be read as an exemplary case of dialogic teaching in the sense in which Alexander (2006) used. It is collective in the sense that the teachers and the children address the learning content of the circle time together while discussing a sensitive topic about different forms of love. It is reciprocal and supportive: the teachers and the children share ideas without fear of embarrassment and help each other to reach common understanding about the importance of freedom when it comes to love. The circle time is also cumulative and purposeful as the narrative's moral dimension is constructed through building on each others' ideas and chain them into a coherent whole with a particular educational goal to use Valentine's day as an occasion to discuss the message of love. Thereby, the circle time discussion enables collaborative meaning making as far as the tradition of celebrating Valentine's day in Sweden is concerned (Fig. 3). 


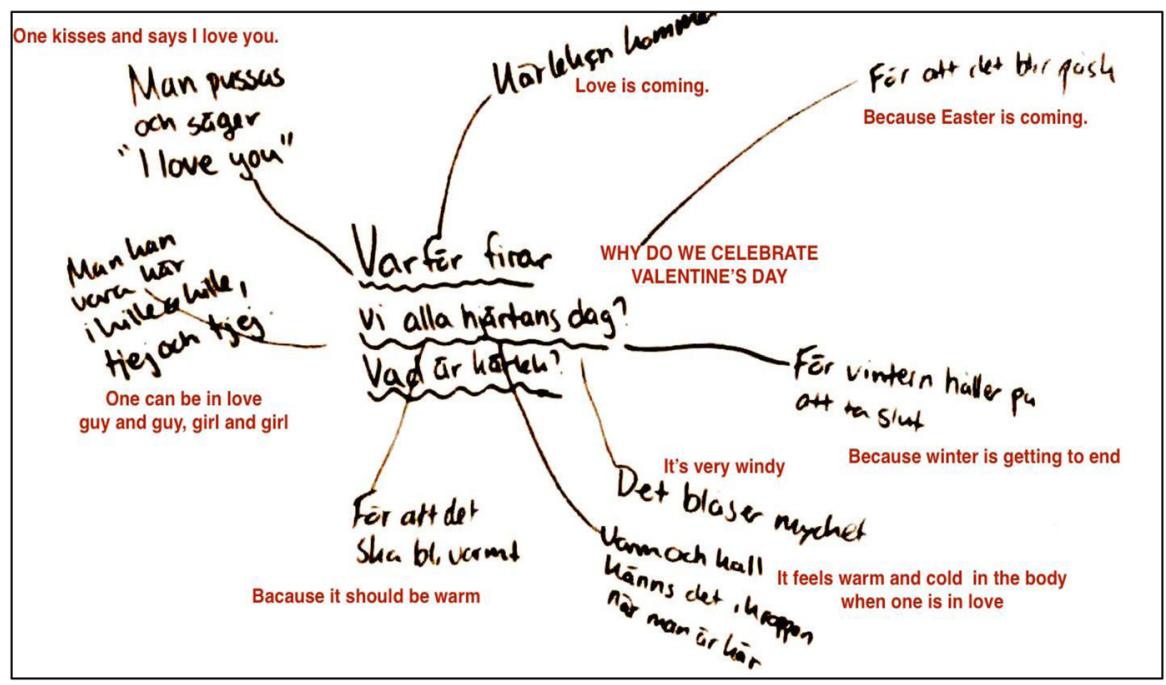

Fig. 3 Mindmap constructed from children's responses to the teacher's question: "Why do we celebrate Valentine's day?"

\section{Discussion}

In the beginning of this paper we raised the question how traditions celebrated in Sweden are filled with meaning in an ethnically diverse preschool. The analysis of circle time discussions reveals that the same question asked during three different circle times poses different challenges to the teachers. All three circle time discussions were permeated with ideas about dialogic teaching whereupon the teachers tried to balance between enacting the children's own ideas and the goal of the curriculum to pass on "a cultural heritage" (Swedish National Agency for Education 1998/2010). Nevertheless, this pedagogical stance, as our examples show, may lead to didactic dilemmas about how to pass on a cultural heritage, without reproducing cultural narratives with a religious connotation. One of the postulates of Alexander's model of dialogic teaching is that the teachers have a particular educational goal in view with the activity. In the discussion on Valentine's day the teachers referred back to a story the children were familiar with and which included a moral aspect that was identified as an educational goal by the teachers. In the other two cases the teachers relied on the children' own experiences and views to a larger extent and, as the children lacked any requisite knowledge, the teachers leading the circle time discussions about Christmas and Easter did not reach their educational goal, i.e., did not provide an answer to the question stated as the focus of the activity. Moreover, the comparison of how different traditions are filled with meaning also reveals that while the teachers do not seem to be worried about discussing sensitive issues related to love they seem to be uncertain about how to pass on culturally sensitive narratives, in this case the ones which have a religious connotation like the one's about Jesus birth and death. 
The Swedish preschool curriculum stipulates that one of the tasks of the preschool is to pass on "a cultural heritage-its values, traditions and history, language and knowledge-from one generation to the next" (Swedish National Agency for Education 1998/2010, p. 5). Religion is specifically identified as part of a cultural heritage, consequently it is left up to the preschool teachers to deal with the religious aspects of traditions. Thus, while preschool teachers are expected to pass on a cultural heritage, that is in many respects based on a Christian ground (Lappalainen 2006, 2009; Modéus 2000), the teachers have to determine where the boundary goes between culture and religion. This can explain why the narratives about why we celebrate Christmas and Easter are treated differently than the narrative that is offered as an answer to the question "Why do we celebrate Valentine's day?"

Our examples also show, that while cultural narratives are treated by the teachers as basic devices for socialization in a culture, as well as an instruments of meaning making (Bruner 1984) the retellings of cultural narratives are infused with ideas about what is "retellable" and how in a given context. At the same time the issues of "what and how" are infused with ideologies surrounding the educational context. This is probably why it is easier for the preschool teachers to offer narratives the moral of which is promoted by the curriculum than to offer a narrative that can be understood as religious, an aspect that is left out from the cultural heritage concept described in the same policy document. However, the avoidance of narratives that can be perceived as religious also entails that the moral dimension of these narratives disappears.

As our examples show the logic of this play are at times in conflict with the idea about passing on a cultural heritage, in particular those which include religious aspects. At the same time the preschool as an institution fills the celebrated traditions with a reconstructed meaning in terms of addressing certain aspects and avoiding others. Thereby, the preschool can be seen both as a keeper of traditions and an agent of change.

\section{Conclusions}

The preschool appears as a context within which cultural narratives are challenged by bringing them into a dialogic play. Central to Bakhtin's notion of adressivity and Alexander's dialogic model of teaching is enabling collaborative meaning making. Nevertheless, in order for collaborative meaning making to happen, teachers need to find a balance between treating children as anticipated contributors and cultural novices. Furthermore, the analysis highlights the didactic dilemmas that arise in the intersection of non-confessional education and the cultural narratives infused with religious connotation. While cultural narratives in general are used as instruments of socialization into a cultural heritage, the analysis indicates that when preschool teachers feel secure about the content of a narrative they do a better work with dialogic teaching.

Moreover, the analysis shows that narratives with a religious tonality generate some uncertainty on how to communicate with the children about the traditions that 
are being discussed. This uncertainty could be explained in three different ways. First, the curriculum does not specifically state whether religion is considered part of the cultural heritage and thus preschool teachers are given the task to decide for themselves, which cultural narratives are retellable and should be treated as transmittable. Second, preschool teachers may lack sufficient knowledge about cultural narratives with a religious connotation, because religion is not an integral part of their education. Third, preschool teachers may have the knowledge about the content of religious narratives but they consider these narratives too complex and are uncertain about how to explain them in a meaningful way. Regardless which scenario is correct, the findings in this study indicate that dialogic teaching is not simply about what is accomplished in teacher-children interaction but it also relates to the cultural and ideological context the teaching takes place in. Therefore, creating bridges between the curricular content and the children's experiences and views remains a didactic challenge.

Acknowledgements The research has been founded by the Swedish Research Council. Award Number: 721-2014-2397.

Open Access This article is distributed under the terms of the Creative Commons Attribution 4.0 International License (http://creativecommons.org/licenses/by/4.0/), which permits unrestricted use, distribution, and reproduction in any medium, provided you give appropriate credit to the original author(s) and the source, provide a link to the Creative Commons license, and indicate if changes were made.

\section{References}

Alexander, R. (2006). Towards dialogic teaching: Rethinking classroom talk. Cambridge: Dialogos.

Alvestad, M., \& Samuelsson, I. P. (1999). A comparison of the national preschool curricula in Norway and Sweden. Early Childhood Research \& Practice, 1(2), 1-21.

Bakhtin, M. (1986). Speech genres and other late essays. Austin: University of Texas Press.

Bruner, J. (1984). Vygotsky's zone of proximal development: The hidden agenda. New Directions for Child and Adolescent Development, 23, 93-97.

Bruner, J. S. (1996). The culture of education. Cambridge, Mass: Harvard University Press.

Ehn, B. (1983). Ska vi leka tiger? Daghemsliv ur kulturell synvinkel (Should we play tiger? Kindergarten life from a cultural perspective). Lund: LiberFörlag.

Hobsbawn, E. J. (1983). Introduction: Inventing traditions. In E. J. Hobsbawn \& T. O. Ranger (Eds.), The invention of tradition. Cambridge: Cambridge University Press.

Jordan, B., \& Henderson, A. (1995). Interaction analysis: Foundations and practice. The Journal of the Learning Sciences, 4(1), 39-103.

Lappalainen, S. (2006). Liberal multiculturalism and national pedagogy in a Finnish preschool context: Inclusion or nation-making? Pedagogy, Culture \& Society, 14(01), 99-112.

Lappalainen, S. (2009). Making differences and reflecting on diversities: Embodied nationality among preschool children. International Journal of Inclusive Education, 13(1), 63-78.

Lilja, A. (1998). Sockrade hjärtan och godissugna spöken: Alla Hjärtans Dag och Halloween-två nya festseder $i$ Sverige (Sugared hearts and ghosts craving for candies: Valentine's Day and Halloween-Two new traditions in Sweden). Stockholm: Språk- och Folkminnesinstitutet.

Modéus, M. (2000). Tradition och liv (Tradition and life). Stockholm: Verbum.

Mosley, J. (2005). Circle time for young children. New York, NY: Routledge.

Ødegaard, E. E. (2007). What's up on the teachers' agenda? International Journal of Early Childhood, $39(2), 45-64$. 
Pramling Samuelsson, I., \& Asplund Carlsson, M. (2003). Det lekande lärande barnet (The playing learning child). Stockholm: Liber.

Reich, L. R. (1994). Circle time in preschool: An analysis of educational praxis. European Early Childhood Education Research Journal, 2(1), 51-59.

Stephens, J., \& McCallum, R. (1998). Retelling stories, framing culture: Traditional story and metanarratives in children's literature. London: Garland Publishing Inc.

Swahn, J. (2012). Swedish traditions. Bromma: Ordalaget.

Swedish National Agency for Education. (1998/2010). Läroplan för förskolan, Lpfö 98 (Curriculum for the preschool, Lpfö 1998). Stockholm: Fritzes förlag.

Swedish National Agency for Education. (2013) Elever i obligatoriska skolan läsåret 2012/13 (Pupils within the Obligatory School System). Retrieved from http://www.skolverket.se/polopoly_fs/1. 194739!/Menu/article/attachment/PM\%20Obligatoriska\%20skolan\%20Elever\%20130327.pdf. 